\title{
KERAGAMAN GENETIK IKAN KAKAP PUTIH (Lates calcarifer Bloch, 1790) TIPE LIAR DAN DOMESTIKASI MENGGUNAKAN METODE Random Amplified Polymorphic DNA (RAPD)
}

\author{
Irmawati $^{a, *}$, Basse Siang Parawansa ${ }^{a}$, Asmi Citra Malina A.R Tassakka ${ }^{a}$, Ma'rifa Baharuddin ${ }^{\text {, }}$, \\ Siti Halimah Larekeng
}

${ }^{a}$ Fakultas Ilmu Kelautan dan Perikanan Universitas Hasanuddin, Jl. Perintis Kemerdekaan Km.10

Makassar 90245, Indonesia

${ }^{\mathrm{b}}$ Alumni Fakultas Ilmu Kelautan dan Perikanan Universitas Hasanuddin, J1. Perintis Kemerdekaan Km.10

Makassar 90245, Indonesia

${ }^{c}$ Fakultas Kehutanan Universitas Hasanuddin, Jl. Perintis Kemerdekaan Km.10 Makassar 90245, Indonesia

*Koresponden penulis : trif.ahwa@gmail.com

\begin{abstract}
Abstrak
Kegiatan pembesaran ikan kakap putih di beberapa Kabupaten di Sulawesi Selatan yang menggunakan benih yang diproduksi dari balai perikanan di Sulawesi Selatan dan Ambon telah berkembang selama beberapa tahun terakhir. Akan tetapi, benih yang dihasilkan dari kegiatan pembenihan tersebut memiliki kualitas yang masih rendah yang diduga karena keragaman genetik yang rendah. Penelitian ini menggunakan metode Random Amplified Polymorphic DNA, RAPD untuk menganalisis variasi genetik ikan kakap putih tipe liar dari Bulungan Kalimantan Utara dan ikan hasil domestikasi dari panti pembenihan di Ambon yang dibesarkan di tambak rakyat di Desa Borongkalukua Kabupaten Maros Sulawesi Selatan. Hasil penelitian menunjukkan bahwa ikan kakap putih tipe liar memiliki nilai heterozigositas yang lebih tinggi dibandingkan dengan ikan kakap putih hasil domestikasi. Jarak genetik antar individu-individu di dalam populasi tipe liar lebih tinggi dibandingkan dengan jarak genetik individu-individu hasil domestikasi. Dendogram dan pohon filogenetik yang dibentuk berdasarkan evolutionary dissimilarity menunjukkan bahwa pada tingkat ketidakmiripan 10\% ikan kakap putih tipe liar dari Bulungan Kalimantan Timur membentuk klaster yang terpisah dengan ikan kakap putih hasil domestikasi dari Ambon yang dipelihara di tambak Dusun Borongkalukua Kabupaten Maros. Keragaman genetik ikan hasil domestikasi lebih rendah dibandingkan ikan tipe liar dan menunjukkan pola evolusi yang pholyphyly Hasil yang diperoleh tersebut menunjukkan bahwa marka RAPD dapat digunakan untuk menganalisis keragaman genetik antara populasi ikan kakap putih tipe liar dan hasil domestikasi serta bermanfaat sebagai informasi dalam menyusun strategi pemanfaatan wild population sebagai sumber induk dan konservasi plasma nutfah ikan kakap putih.
\end{abstract}

Kata kunci: heterozigositas, ikan kakap putih, Random Amplified Polymorphic DNA RAPD, variasi genetik

\begin{abstract}
In recent years the grow-out out of Asian seabass (Lates calcarifer) has become widespread in several regencies across South Sulawesi, using seed produced by hatcheries in South Sulawesi and Ambon. However, the quality of the seed produced has remained quite low, which is thought to be due to low genetic variation. This research used a Random Amplified Polymorphic DNA (RAPD) method analyse the genetic variation in wild Asian seabass from Bulungan in East Kalimantan and domesticated fish from the Ambon hatchery raised in ponds in Borongkalukua Village, Maros Regency, South Sulawesi. The results showed that heterozygosity was higher in wild-type than in domesticated Asian seabass. Using a 10\% dissimilarity level, the dendrogram and phylogenetic tree based on evolutionary dissimilarity showed that wild-type Asian seabass from Bulungan in East Kalimantan formed a clade which was well separated from the clade comprising the domesticated Asia seabass reared in Borongkalukua, Maros Regency. Genetic diversity was lower in domesticated than in wild-type fish, with a polyphilic evolutionary pattern. The results show that RAPD markers can be used to analyse between-population genetic diverisity in wild-type and domesticated Asian seabass and can be used to inform strategies for using wild populations as a source of broodstock and to conserve within-species genetic diversity of Asian seabass.
\end{abstract}


The genetic distance between the wild type is higher than the domesticated fishes. Phylogenetic trees formed based on evolutionary dissimilarity show that the wild type Asian seabass form separate clusters from domesticated Asian seabass. The genetic diversity of domesticated fish is lower than wild type and shows a polyphyly evolutionary pattern. The results obtained indicate that the RAPD markers can be used to analyse genetic diversity wild type Asian seabass and are useful as database in formulating strategies for using wild population as brood stock. There are useful in monitoring genetic diversity of cultured stocks and for conservation Asian seabass germplasm.

Keywords: Asian seabass, genetic variance, Lates calcarifer, Random Amplified Polymorphic DNA RAPD

\section{PENDAHULUAN}

Ikan kakap putih (Lates calcarifer Bloch, 1790) yang populer dikenal dengan nama dengan nama barramundi di Australia dan Asian Seabass serta salmon Asia di Asia adalah ikan jenis katadromous dan hermafrodit. Ikan kakap putih merupakan ikan budidaya komersial di Australia, Asia Tenggara dan saat ini telah dibudidayakan di Amerika Utara dan Eropa [1]. Pada tahun 2018, FAO memperkenalkan ikan kakap putih sebagai spesies diversifikasi pada akuakultur [2]. Hal tersebut karena ikan kakap putih memiliki banyak keunggulan seperti laju pertumbuhan yang cepat, fekunditas yang tinggi, teknik pembenihan yang mudah di wadah terkontrol, dan kemampuan adaptasi yang tinggi terhadap berbagai kondisi lingkungan [3]. Pembesaran ikan kakap putih dapat dilakukan di air tawar, air payau, maupun air bersalinitas, di kolam, tambak atau keramba jaring apung (KJA). Di Indonesia, produksi ikan kakap putih terus dikembangkan melalui penerapan teknologi KJA offshore dan teknologi pembesaran di tambak dengan target produksi sebesar 31,3 juta ton pada tahun 2019.

Kegiatan pembenihan ikan kakap putih di Indonesia hingga saat ini masih mengandalkan wild population sebagai sumber induk dan sumber induk tersebut belum di karakterisasi status stoknya. Berbeda dengan Singapura yang telah menerapkan manajemen induk ikan Asian Seabass berbasis kontrol keanekaragaman genetik sejak tahun 1998. Mereka telah menganalisis keanekaragaman genetik ikan kakap putih wild stok dan culture stock berdasarkan gen D-loop DNA mitokondria [4], mengembangkan mikrosatelit yang polimorfik $[5,6,7]$ dan mengkarakterisasi serta mengonstruksi 240 mikrosatelit ke dalam sebuah genetic linkage map atau peta genetik yang terkait karakter produktivitas [8].
Analisis keragaman genetik dapat dilakukan dengan menggunakan penanda molekuler. Penanda molekuler merupakan karakter yang dapat diturunkan dan berasosiasi dengan genotipe tertentu. Penanda molekuler antara lain adalah Random Amplified Polymorphic DNA (RAPD) yang berbasis PCR yang banyak digunakan dalam mengidentifikasi keragaman pada tingkat interspesies maupun antar spesies. Teknik ini memiliki kelebihan dalam pelaksanaan dan analisisnya. Dibandingkan dengan Simple Sequence Repeat (SSR), teknik RAPD lebih murah, mudah dilakukan, cepat memberikan hasil, menghasilkan polimorfisme pita DNA dalam jumlah banyak serta primer acak yang digunakan mudah diperoleh [9].

Sejak tahun 2018, budidaya kakap putih di tambak dan keramba jaring apung (KJA) di Sulawesi Selatan mulai diminati. Akan tetapi, sejumlah masalah di lapangan ditemui antara lain mortalitas dan tingkat abnormalitas yang masih tergolong tinggi pada ikan hasil budidaya. Hal tersebut terjadi karena jumlah populasi efektif yang digunakan pada kegiatan pembenihan kecil yang menyebabkan keragaman genetik progeni rendah akibat genetic drift [10]. Selain itu penggunaan induk yang secara terus menerus (induk afkir) juga menjadi salah satu penyebab menurunnya keragaman genetik pada benih yang diproduksi dari suatu kegiatan pembenihan (hatchery).

Keragaman genetik mempunyai arti penting dalam stabilitas dan ketahanan populasi. Keragaman genetik yang tinggi diperlukan untuk mempertahankan kelangsungan hidup populasi dan spesies dari serangan hama dan penyakit. Banyak faktor yang mempengaruhi besarnya nilai keragaman genetik, di antaranya sifat reproduksi dan habitat di alam [11]. Stok kakap putih di perairan Indonesia, yang dapat dijadikan sebagai sumber induk, tersedia cukup melimpah, diantaranya berlokasi di perairan 
Kabupaten Bulungan Kalimantan Utara. Berdasarkan hal tersebut, maka penelitian ini dilakukan untuk mengkaji keragaman genetik genom ikan kakap putih wild stock di perairan Kabupaten Bulungan dan ikan kakap putih hasil domestikasi di Sulawesi Selatan dengan menggunakan metode RAPD sebagai langkah awal untuk menyediakan data dalam merakit induk unggul pada kegiatan pembenihan dan konservasi plasma nutfah ikan kakap putih.

\section{METODE}

\section{Sampel Ikan Kakap Putih}

Sampel ikan kakap putih wild stock berasal dari ikan liar yang masuk ke tambak udang di Kabupaten Bulungan, Kalimantan Utara. Sampel ikan kakap putih hasil domestikasi adalah ikan hasil kegiatan pembenihan Balai Perikanan Budidaya Laut (BPBL) Ambon yang dibesarkan di tambak di Dusun Borongkalukua Desa Borimasunggu Kecamatan Maros Baru Kabupaten Maros Sulawesi Selatan (Gambar 1 dan Tabel 1).

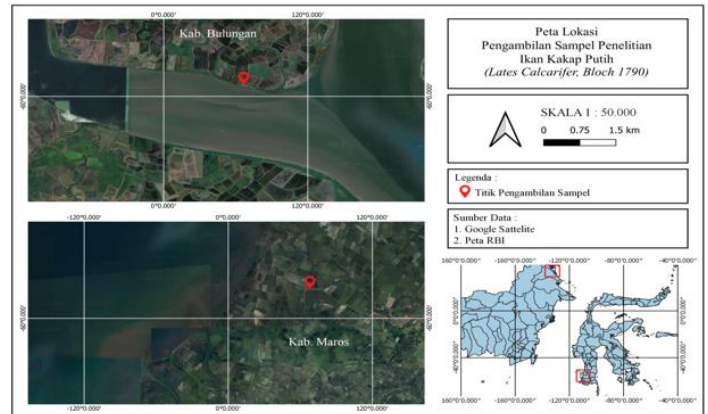

Gambar 1. Peta lokasi pengambilan sampel ikan kakap putih (Lates calcarifer Bloch, 1790) di Kabupaten Bulungan, Kalimantan Utara dan di Dusun Borongkalukua Desa Borimasunggu Kecamatan Maros Baru Kabupaten Maros Sulawesi Selatan

Tabel 1. Lokasi pengambilan sampel dan jumlah sampel ikan kakap putih (Lates calcarifer Bloch, 1790)

\begin{tabular}{lcc}
\hline Lokasi & $\begin{array}{c}\text { Jumlah } \\
\text { Sampel }\end{array}$ & Titik Koordinat \\
\hline Tambak Kabupaten & & $3^{\circ} 20^{\prime} 32.776^{\prime \prime} \mathrm{N}$, \\
$\begin{array}{l}\text { Bulungan } \\
\text { Kalimantan Utara }\end{array}$ & 10 & $1^{10} 29^{\prime} 14.0352^{\prime} \mathrm{E}$ \\
Tambak Dusun & & \\
$\begin{array}{l}\text { Borongkalukua, } \\
\text { Desa Borimasunggu, }\end{array}$ & 9 & $4^{0} 58^{\prime} 22.443^{\prime \prime} \mathrm{S}$, \\
Kecamatan Maros & & $11^{\circ} 30^{\prime} 32.422^{\prime} \mathrm{E}$ \\
\hline
\end{tabular}

101

\begin{tabular}{ll}
\hline $\begin{array}{l}\text { Baru, Kabupaten } \\
\text { Maros }\end{array}$ \\
\hline Jumlah & 19 \\
\hline
\end{tabular}

Sampel ikan ditangkap dengan menggunakan gillnet, diawetkan dengan menggunakan es batu sebelum dilakukan pengambilan sampel otot untuk analisis DNA. Sampel otot diambil pada bagian punggung ikan dan diawetkan di dalam etanol absolut sebelum digunakan untuk tahap analisis berikutnya.

\section{Isolasi dan Kuantifikasi Genom Ikan Kakap Putih}

Genom ikan kakap putih diisolasi menggunakan DNeasy Blood \& Tissue Kit (QIAGEN, Germany) mengikuti protokol. Genom atau total DNA dianalisis menggunakan Kit Qubit dsDNA BR (broad range) Assay (Invitrogen, USA).

\section{PCR-RAPD (Polymerase Chain Reaction- Random Amplified Polymorphic DNA)}

PCR-RAPD diawali dengan seleksi primer dan penentuan suhu optimum untuk setiap primer. Primer yang digunakan adalah primer yang memberi pola pita yang polimorfik (Tabel 2).

Tabel 2. Primer oligonukleotida dan suhu annealing yang digunakan pada analisis keragaman genetik ikan kakap putih (Lates calcarifer Bloch, 1790)

\begin{tabular}{ccc}
\hline Primer & Urutan Sekuen Nukleotida & $\begin{array}{c}\text { Suhu } \\
\left({ }^{\mathbf{} C)}\right.\end{array}$ \\
\hline OPQ-07 & 5'-CCC CGA TGG T-3' & 41,1 \\
OPD-20 & 5'ACC CGG TCA C-3' & 39,7 \\
OPC-11 & 5'AAA GCT GCG G-3' & 38,7 \\
\hline
\end{tabular}

Reaksi PCR-RAPD terdiri dari $3 \mu \mathrm{L}$ nuclease free water, $6,25 \mu \mathrm{L}$ PCR mix KAPPA, $1,25 \mu \mathrm{L}$ primer, dan $3 \mu \mathrm{L}$ DNA sehingga volume total PCR mix adalah 13,5 $\mu \mathrm{L}$. Amplifikasi PCR di running pada kondisi: denaturasi awal pada suhu $95^{\circ} \mathrm{C}$ selama tiga menit kemudian dilanjutkan 35 siklus denaturasi pada suhu $95^{\circ} \mathrm{C}$ selama 30 detik, annealing atau penempelan primer pada suhu $56,4^{\circ} \mathrm{C}$ (tergantung primer) selama 50 detik dan extention atau perpanjangan DNA pada suhu $72^{\circ} \mathrm{C}$ selama satu menit. Amplifikasi 
DNA diakhiri dengan proses perpanjangan DNA pada suhu $72^{\circ} \mathrm{C}$ selama lima menit dan setelah itu hasil amplifikasi disimpan pada suhu $4^{\circ} \mathrm{C}$ selama waktu $\sim$ (tak terhingga).

\section{Elektroforesis}

Elektroforesis dilakukan dengan merunning DNA hasil PCR-RAPD pada $1 \%$ gel agarose di dalam larutan buffer elektroforesis. Kondisi elektroforesis adalah 100 volt, 90 menit. DNA divisualisasikan di bawah sinar UV transluminator di dalam gel doc. Pita-pita terang yang terlihat merupakan segmen-segmen DNA hasil amplifikasi yang menunjukkan variasi genetik sampel ikan kakap putih.

\section{Analisis Data}

Analisis data diawali dengan melakukan skoring pita-pita DNA berdasarkan ukurannya. Skoring dilakukan dengan bantuan ladder 100 $b p$ (Invitrogen). Pita DNA diubah ke dalam data biner berdasarkan ukurannya dan dianalisis menggunakan software Darwin 6.0 untuk menentukan jarak genetik intra dan antar populasi dan polimorfisme individu di dalam populasinya.

\section{HASIL DAN PEMBAHASAN}

\section{Keragaman Genetik Ikan Kakap Putih (Lates calcarifer, Bloch 1790)}

Keragaman genetik ikan kakap putih berupa nilai heterozigositas disajikan pada Tabel 3. Heterozigositas ikan kakap putih di perairan Bulungan tidak berbeda nyata dengan heterozigositas ikan kakap putih domestikasi Ambon yang tertangkap di tambak Dusun Borongkalukua Desa Borimasunggu Kecamatan Maros Baru Kabupaten Maros Sulawesi Selatan. Heterozigositas menunjukkan potensi suatu individu untuk beradaptasi terhadap lingkungannya. Nilai heterozigositas yang semakin tinggi menunjukkan semakin banyak gen yang berperan dalam kebugaran suatu populasi [12].
Tabel 3. Nilai heterozigositas populasi ikan kakap putih (Lates calcarifer, Bloch 1790) dari tambak Bulungan dan dari Balai Perikanan Budidaya Laut (BPBL) Ambon yang dibesarkan di tambak Desa Borongkalukua Kabupaten Maros

\begin{tabular}{lcc}
\hline Populasi & Primer & Heterozigositas \\
\hline $\begin{array}{l}\text { Wild type } \\
\text { Bulungan }\end{array}$ & OPQ-07 & \\
& OPD-20 & 0.316 \\
OPC-11 & \\
$\begin{array}{l}\text { Domestikasi } \\
\text { Ambon }\end{array}$ & OPQ-07 & \\
& OPD-20 & 0.246 \\
\hline
\end{tabular}

\section{Jarak Genetik Ikan Kakap Putih (Lates calcarifer Bloch, 1790)}

Jarak genetik antar individu ikan kakap putih tipe liar Bulungan berkisar antara 0.070 0.526 sedangkan jarak genetik antar individu ikan kakap putih terdomestikasi Ambon berkisar antara 0.019-0.286. Hal tersebut menunjukkan bahwa kegiatan domestikasi dan budidaya mereduksi keragaman genetik. Fenomena yang menunjukkan bahwa kegiatan domestikasi mereduksi keragaman genetik juga terlihat pada kegiatan domestikasi ikan kerapu tikus (Cromileptes altivelis) [13]. Reduksi keragaman genetik pada kegiatan pembenihan (domestikasi) disebabkan oleh genetic drift akibat jumlah populasi efektif atau jumlah induk yang terlibat pada kegiatan reproduksi ukurannya kecil dibandingkan dengan ikan-ikan yang melakukan breeding atau kawin secara alami.

Tabel 4. Jarak genetik ikan kakap putih (Lates calcarifer, Bloch 1790)

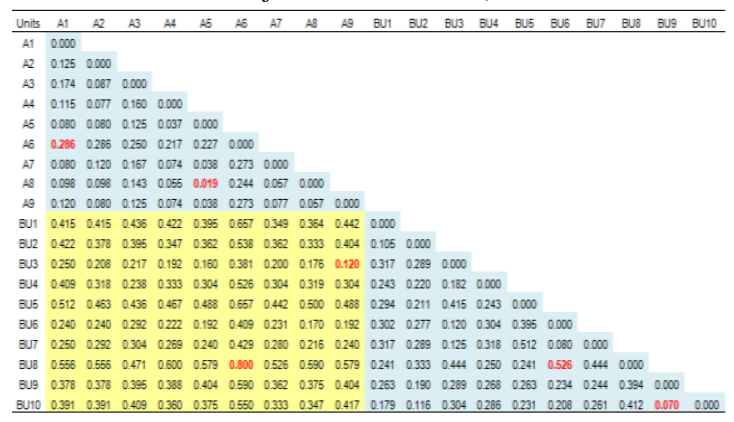

Jarak genetik antara populasi ikan kakap putih tipe liar Bulungan dengan ikan kakap putih terdomestikasi Ambon berkisar antara $0.120-0.800$. 


\section{Filogenetik}

Dendrogram dan pohon filogenetik yang dibentuk berdasarkan evolutionary dissimilarity disajikan pada Gambar 2 dan 3. Pohon filogenetik yang direkonstruksi berdasarkan fragmen DNA menggunakan metode RAPD secara akurat dapat mencerminkan sejarah divergensi populasi. Hal tersebut terlihat jelas bahwa pada tingkat ketidakmiripan $10 \%$ atau tingkat kemiripan $90 \%$ ikan kakap putih tipe liar asal perairan Bulungan, Kalimantan Utara terpisah dari ikan kakap putih terdomestikasi asal Ambon yang dibesarkan di tambak Dusun Borongkalukua, Kabupaten Maros. Ikan kakap puth terdomestikasi asal Ambon dan Bulungan masing-masing membentuk dua klaster dan terdapat satu individu (A7) dari Ambon dan tiga individu (BU3, BU6, BU7) dari Bulungan yang memisah dari populasinya.

Ikan kakap putih hasil domestikasi menunjukkan pola evolusi yang polyphyly dibandingkan dengan ikan kakap putih wild type dari Bulungan Kalimanta Utara yang cenderung monophyly. Hal tersebut sesuai dengan tujuan kegiatan hibridisasi yang lebih mengharapkan hasil yang polyphyly. Ikan kakap putih yang dibudidayakan di French Polynesia yang induknya berasal dari Singapura berbeda klaster dengan ikan kakap putih hasil domestikasi di Singapura yang sekuensnya terdeposit di GenBank (DQ010541) [14].

Salah satu penyebab polyphyly adalah accasional mating yang mengakibatkan transfer alel induk ke keturunannya [15]. Penyebab lainnya adalah alel suatu spesies yang terintegrasi ke dalam gene pool spesies lainnya akibat perkawinan interspesifik dan backcrossing hibrida ke parental population yang juga dikenal dengan istilah introgressive, hybridization, introgression, atau interspecific gene flow. Introgression menghasilkan polyphyly dengan mengintroduksikan alel yang berbeda secara phylogenetic melintasi batas spesies $[16,17,18,19]$. Hibrida yang terbentuk dari hibridisasi asimetri berulang akan menjadi monophyletic apabila haplotype mitokondria ikan betina semuanya adalah identik [20].

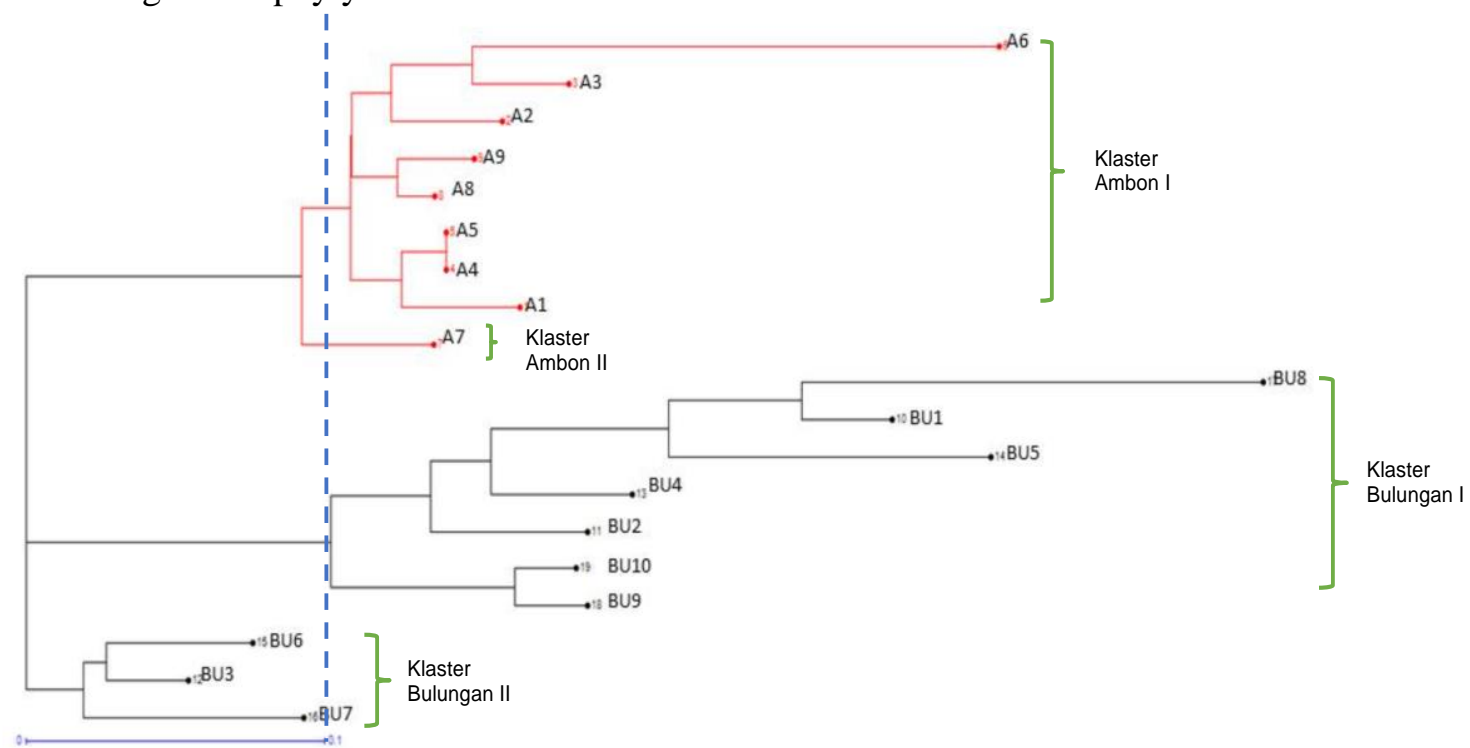

Gambar 2. Dendogram ikan kakap putih (Lates calcarifer, Bloch 1790) wild type dari perairan Bulungan Kalimantan Utara dan ikan kakap putih hasil domestikasi di Balai Perikanan Budidaya Laut (BPBL) Ambon yang dibesarkan di tambak Desa Borimasunggu Kabupaten Maros Sulawesi Selatan 


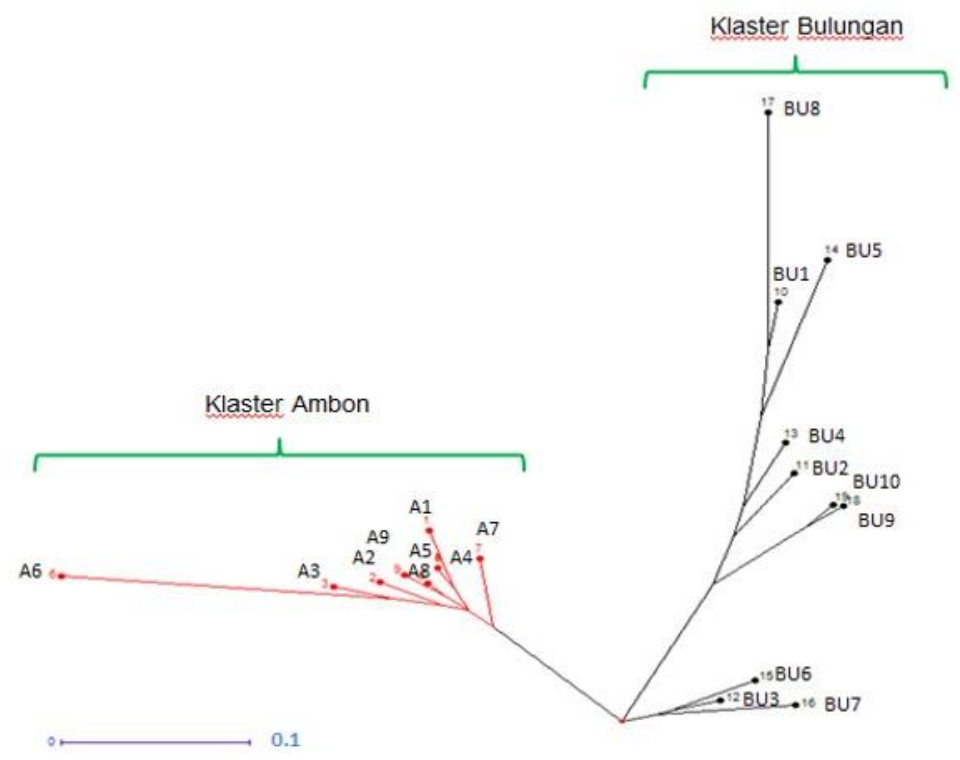

Gambar 3. Pohon filogenetik ikan kakap putih (Lates calcarifer, Bloch 1790) wild type dari perairan Bulungan Kalimantan Utara dan ikan kakap putih hasil domestikasi di Balai Perikanan Budidaya Laut (BPBL) Ambon yang dibesarkan di tambak Desa Borimasunggu Kabupaten Maros Sulawesi Selatan

\section{KESIMPULAN}

Keanekaragaman genetik ikan kakap putih tergolong rendah dan keragaman genetik ikan hasil domestikasi lebih rendah dibandingkan ikan tipe liar. Ikan kakap putih hasil domestikasi dari Ambon yang dibesarkan di tambak di Dusun Borongkalukua Kabupaten Maros menunjukkan pola evolusi yang polyphyly dibandingkan dengan ikan kakap putih wild type dari Bulungan Kalimantan Utara yang cenderung monophyly.

\section{UCAPAN TERIMA KASIH}

Ucapan terima kasih kepada Universitas Hasanuddin yang telah membiayai penelitian ini melalui Hibah Penelitian Dosen Pembimbing Akademik (PDPA) tahun anggaran 2020 dengan nomor kontrak 1585/UN4.22/PT.01.03/2020. Ucapan terima kasih kepada seluruh staf Laboratorium Bioteknologi dan Pemuliaan Pohon Fakultas Kehutanan Universitas Hasanuddin atas bantuan sarana dan prasaran selama penelitian.

\section{DAFTAR PUSTAKA}

[1] R.B. Katersky, C.G. Carter, "A preliminary study on growth and protein synthesis of juvenile barramundi, Lates calcarifer at different temperatures," Aquaculture, vol. 267, hal. 157-164, 2007.

[2] FAO, "The State of World Fisheries and Aquaculture Meeting the Sustainable," Development Goals, Rome, hal. 227, 2018.http://www.fao.org/3/i9540en/i95 40en.pdf.

[3] G. Mathew G, "Taxonomy, identification and biology of Sea bass (Lates calcarifer). In: Imelda J, Edwin JV, Susmitha V. (Eds.), Course Manual: National Training on Cage Culture of Sea Bass," CMFRI \& NFDB, Kochi, hal 38-43, 2009.

[4] G. Lin, L.C. Lo, Z.Y. Zhu, F. Feng, R. Chou, G.H. Yue, "The complete mitochondrial genome sequence and characterization of single-nucleotide polymorphisms in the control region of the Asian seabass (Lates calcarifer)," Marine Biotechnology, vol. 8, hal. 7179, 2006.

[5] Z.Y. Zhu, G. Lin, L.C. Lo, Y.X. Xu, C. Renee, G.H. Yue, "Genetic analyses of 
Asian seabass stocks using novel polymorphic microsatellites," Aquaculture, vol. 256, hal. 167-173, 2006.

[6] G.H. Yue, Y. Li, T.M. Chao, R. Chou, L. Orban, "Novel microsatellites from Asian seabass (Lates calcarifer) and their application to broodstock analysis," Marine Biotechnology, vol. 4, hal. 503511, 2002.

[7] G. Yue, Y. Li, L. Orban, "Characterization of microsatellites in the IGF-2 and GH genes of Asian seabass (Lates calcarifer)," Marine Biotechnology, vol. 3, hal. 1-3, 2001.

[8] C.M. Wang, Z.Y. Zhu, L.C. Lo, F. Feng, G. Lin, W.T. Yang, J. Li, G.H. Yue, 'A microsatellite linkage map of Barramundi, Lates calcarifer," Genetics, vol. 175, hal. 907-915, 2007.

[9] Irmawati, "Genetika Populasi Ikan", ANDI, Yokyakarta, 244 hal., 2016.

[10] Irmawati, Alimuddin, A.C.M.A.R. Tassakka, "Budidaya Ikan Kakap Putih (Lates calcarifer Bloch, 1790) Berbasis Ekosistem" Dokumen Kebijakan, Lembaga Penelitian dan Pengabdian pada Masyarakat, Universitas Hasanuddin, 26 hal., 2019.

[11] J.L. Hamrick, M.J.W. Godt, S. Broyless, "Factor influencing levels of genetic diversity in woody plant species," New Forest, vol. 6, hal. 95-124, 1992.

[12] D. Tave, "Inbreeding and Broostock Management", Fisheries Technical Paper, No.392, FAO, Rome, 122p., 1999.

[13] Irmawati, "Perubahan keragaman genetik ikan kerapu tikus (Cromileptes altivelis) generasi pertama pada stok hatchery", Program Pasca Sarjana, Institut Pertanian Bogor, Bogor, 53 hal., 2003.
[14] G. Lin, L.C. Lo, Z.Y. Zhu, F. Feng, R. Chou, G.H. Yue, "The complete mitochondrial genome sequence and characterization of single-nucleotide polymorphisms in the control region of the Asian seabass (Lates calcarifer), Marine Biotechnology, vol. 8, hal. 7179, 2006.

[15] D.J. Funk, K.E. Omland, "Species level paraphyly and polyphyly: frequency, causes, and consequences, with insights from animal mitochondrial DNA, Annual Review Ecology, Evolution, and Systematics", vol. 34, hal. 397-423, 2003.

[16] T.M. Boyce, M.E. Zwick, C.F. Aquadro, "Mitochondrial DNA in the bark weevils: Phylogeny and evolution in the Pissodes strobi species group (Coleoptera: Curculionidae)", Molecular Biology Evolution, vol. 11, hal. 183-194, 1994.

[17] J.L. Patton, M.F. Smith, "Paraphyly, polyphyly, and the nature of species boundaries in pocket gophers (Genus Thomomys)", Systematic Biology, vol. 43, hal. 11-26, 1994.

[18] K.L. Shaw, "A nested analysis of song groups and species boundaries in the Hawaiian cricket genus Laupala", Molecular Phylogeny Evolution, vol. 11, hal. 332-341, 1999.

[19] K.L. Shaw, " Conflict between nuclear and mitochondrial DNA phylogenies of a recent species radiation: what mtDNA reveals and conceals about modes of speciation in Hawaiian crickets", Proc. Natl. Acad. Sci., USA, vol.99, hal. 16122-16127, 2002.

[20] B. Mantovani, M. Passamonti, V. Scali, "The mitochondrial cytochrome oxidase II gene in Bacillus stick insect: ancestry of hybrids, androgenesis, and phylogenetic relationship", Molecular Phylogenetic Evolution, vol. 19, hal. 157-163, 2001. 